\title{
Sciendo
}

RURAL SUSTAINABILITY RESEARCH 45 (340), 2021

ISSN - 2256-0939

(c) Latvia University of Life Sciences and Technologies, all rights reserved http://www.llu.Iv/en/

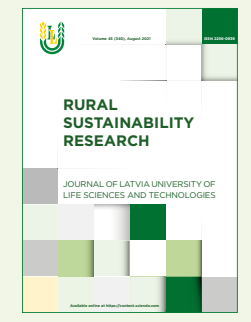

Received: 25 March 2021

Revised: 25 May 2021

Accepted: 29 June 2021

\section{State Decoupling Audit of Low-Carbon Agricultural Production}

\author{
Oleksandr Datsii ${ }^{1}$, Nataliia Levchenko², Ganna Shyshkanova², Ruslan Dmytrenko ${ }^{3}$, George Abuselidze $^{4}$ \\ ${ }^{1}$ Interregional Academy of Personnel Management, Ukraine, \\ ${ }^{2}$ National University Zaporizhzhia Polytechnic, Ukraine, \\ ${ }^{3}$ Vinnytsia National Agrarian University, Ukraine, \\ ${ }^{4}$ Batumi Shota Rustaveli State University, Georgia
}

\begin{abstract}
It is stated that the strategic benchmark for transformational changes in the economy is currently low-carbon production, the achievement of which is possible to provide with the consistent application of an arsenal of strict control measures, in particular, the introduction of state audit of low-carbon production. The effectiveness of the mechanism for ensuring the implementation of the UN Framework Convention on Climate Change has been assessed. The necessity of implementation in the domestic practice of the state audit of low-carbon production by the decoupling approach is proved. The agri-business portfolio has been formed according to the decoupling approach as one of the leaders in greenhouse gas pollution. The author's economic and mathematical models of estimation according to the decoupling approach of the impact of branches of crop and livestock production on environmental pollution are proposed. The dependence of greenhouse gas emissions on the volume of gross output of agricultural production, capital investment and current expenditures on environmental protection has been established. The results of a comparative analysis of the realism of forecasts of changes in greenhouse gas emissions according to the methodology of the National Academy of Sciences of Ukraine and the author's methodology are highlighted. A roadmap for the introduction of a state low-carbon decoupling audit of the state decoupling audit has been proposed as part of the preparation of the second nationally determined contribution to the Paris Agreement. The expediency of supplementing GRI 300 "Environmental Disclosures" with the group of indicators GRI-305.5 "Reduction of GHG emissions", formed by the decoupling approach, is substantiated.
\end{abstract}

Keywords: air pollution; greenhouse gas emissions; low-carbon production; state decoupling audit.

\section{Introduction}

Activation turn of scientific research on the issue of low-carbon production is associated with the Race To Zero movement (a global UNFCCC campaign to bring together politicians and businesses, states, regions and cities, foundations and investors to ensure carbon neutral) is one of the landmark events of the beginning of the XXI century, which determines the formation of an independent scientific direction management of low-carbon production (Lyashenko, 2015), aimed at creating a mechanism for coordination of policy and business, which in the context of climate change will ensure environmental protection, well- being and future generations.

In this context, the issue of ensuring the effectiveness of this mechanism is extremely important, as the action of the first international mechanism of low-carbon development has proved that the Kyoto mechanisms have not had a positive impact on the situation with carbon emissions in the world. Differentiation in approaches, namely exemption from emission reduction commitments for some countries, has resulted in global emissions growth and nullified the achievements of countries that have committed to low-carbon production (Haidutsky, 2017). Consequently, the issue of enhancing the effectiveness

\footnotetext{
* Corresponding Author's email: george.abuselidze@bsu.edu.ge
} 
of the so-called anti-carbon mechanism does not lose its relevance, but on the contrary with the exacerbation of the climate crisis is becoming increasingly important, which is what prompted further research on this issue.

\section{Material and Methods}

It is no secret that a significant cohort of both foreign and domestic politicians, scientists and practitioners have been actively working on the issue of low-carbon production for more than a year (Foxon, 2011; Liu, et al., 2020; Liu, Xu, \& Hao, 2021; Lu, \& Sun, 2021; Shuai, et al., 2019; Zhangping, \& Yintai, 2008; Zhang, et al., 2019; Wu, et al., 2020; TaghizadehToosi, \& Olesen, 2016; Nyambuu, \& Semmler, 2020; Zhan, \& de Jong, 2018; Slobodianyk, \& Abuselidze, 2019). In particular, UN Secretary-General Antonio Guterres emphasizes that existing climate threats, biodiversity crises and environmental pollution require humanity to reflect on the true value of nature. Humanity will ensure the well-being of the planet, and hence the well-being of present and future generations because this is achieved only by understanding its value and directing ingenuity to the transition to lowcarbon production (UNEP, 2021a).

Michael R. Bloomberg, with ten years of experience in combating climate change, emphasizes that the transition to low-carbon production and achieving neutral greenhouse gas (GHG) emissions by 2050 (while changing the biodiversity loss curve) is vital and is a fundamental basis in solving the climate problem of the planet and achieving the goals of sustainable development set by the UN in the medium and long term (Michael).

Patricia Espinosa proves the need to mobilize government, business and citizens as soon as possible to achieve carbon neutrality (UNEP, 2021b). Inger Andersen emphasizes the importance of unity in finding political, economic and innovative solutions to overcome environmental crises related to GHG emissions (UNEP, 2021a).

Richardson K., Steffen W. and Liverman D. argue that the transition to low-carbon production is extremely necessary, but its implementation requires large amounts of investment, which is complicated by their deficit, especially in developing countries (Richardson, Steffen, \& Liverman, 2011).

In particular, authors (Carraro, Favero, \& Massetti, 2012; Owen, Brennan, \& Lyon, 2018; Campiglio, 2016; Monnin, 2018; Abuselidze, 2019) talk about the importance of macroprudential financial regulation in the development of credit policy by banks and the limitations and challenges facing low-carbon enterprises. Due to the fact that low-carbon activities require additional tools, banks refuse low-carbon lending.

Hahnel R. in his work "Green in Economics:
Confronting the Ecological Crisis" argues that innovation and investment should be directed primarily to those activities that protect both people and the environment (Hahnel, 2014). However, we consider such statements to be erroneous, there should not be individual industries, regions, cities or enterprises in which it is worth investing and in which they are not. Authorities, businesses and the public in all countries of the world must be united in overcoming the threats of climate change and the transition to low-carbon production.

I.P. Haidutskyi argues that anti-carbon policy should be unified, global and mandatory. Ensuring low-carbon development with sufficient capital is possible provided that the policies of all parties involved are consistent: international institutions; transnational companies, governments of recipient countries, etc. Policy coherence is the fundamental basis that can ensure the effectiveness of the anti-carbon mechanism and thus can accelerate the transition to low-carbon production (Haidutsky, 2017). In certain economic situations, additional policies are required to increase competition in the banking system and to expand lending to low-carbon activities (Campiglio, 2016; Monnin, 2018; Abuselidze, \& Kizinidze, 2019; Abuselidze, 2021; Louche, \& Marcus, 2019). For example, by differentiating reserve requirements for the purpose of lending, it is possible to create loans for the low carbon sectors. This is possible in developing market economies, where a wide range of monetary policy instruments are represented and the central bank oversees the distribution of credit. Consequently, the issue of finding ways to enhance the effectiveness of this mechanism is topical and requires an immediate search for ways to address them.

Therefore, the aim of the study was to find ways to increase the effectiveness of the coordination mechanism to accelerate the transition to low-carbon production, which in the context of intensifying climate change will ensure the environment, well-being of the planet and their future generations.

The following methods are used in the course of the research: economic and mathematical modeling in determining the dependence of GHG emissions on the volume of gross output of agricultural production and capital investment, the area of agricultural coal and livestock; decoupling analysis - when assessing the impact of agribusiness on the environment; strategic analysis - in assessing the feasibility of the chosen strategy of low-carbon agricultural production; GAPanalysis - in finding ways to achieve the goals of low-carbon agricultural production; forecasting - when determining the volume of GHG emissions under the condition of increasing the volume of agricultural production; abstract and logical - in generalizing the results of the study and formulating conclusions. 


\section{Results and Discussion}

The results of research show that Ukraine has not been left out in resolving the issues of low-carbon production. With the ratification (On ratification of the UN Framework Convention on climate change, 1996) of the UN Framework Convention on Climate Change (UNFCCC) (United nations, 1992), Ukraine acceded to the UNFCCC member states and undertook a set of measures to reduce GHG and periodically publish information on emissions in the National Inventory of Anthropogenic Emissions from sources and removals by sinks of GHG in Ukraine (hereinafter the National Inventory of Anthropogenic Emissions), formed in accordance with the requirements of the Secretariat of the UN Framework Convention on Climate Change (United nations, 1992).

According to the results of the last inspection by the UNFCCC Secretariat of the National Anthropogenic Emission Inventory, carried out in accordance with decisions $20 /$ CP.21 and $10 /$ CMP.11 of the Conferences of the UNFCCC Parties and the Paris Agreement (United Nations, 2015), Ukraine has demonstrated full compliance in the first years. However, we consider it appropriate to emphasize that the most significant decline in GHG emissions in Ukraine was observed during 1990-2000. A detailed study of the basis of these changes in volumes suggests that the reason was not modernization of production and implementation of innovative projects, but the decline of the Ukrainian economy, which led to a dramatic decline in production. A striking example of this is agricultural production, changes in GHG emissions, which we have the opportunity to clearly observe the data in Figure 1.

According to Figure 1 during 1990-2000, GHG emissions from agribusiness decreased many times. At the same time, since 2000 until now a clear tendency of changes in GHG emissions has not been formed. Their volumes from year to year fluctuate with insignificant amplitude. The only thing that is clearly observed in this direction is the increase in carbon emissions from the crop industry while reducing the volume of these emissions from the livestock industry.

According to the National Anthropogenic Emissions Inventory (Ministry of Energy and Environmental Protection of Ukraine, 2019), total GHG emissions in the sector "Agriculture" in 2018 increased by $7.7 \%$ compared to the previous year. However, in 2019 their volumes decreased slightly. According to (Ministry of Energy and Environmental Protection of Ukraine, 2019), the largest increase in GHG emissions is observed in crop production, namely in the category "Agricultural soils". Thus, compared to 1990, GHG emissions in this category decreased by only $11.1 \%$, and compared to the previous 2017 - increased by $12.7 \%$. This dynamic is explained by the growth of areas occupied by arable land, an increase in the amount of mineral fertilizers making the transition to a more unsustainable use of soils with lower rates of organic fertilizers.

Changes in GHG emissions from livestock have resulted in a reduction in the number of farm animals,

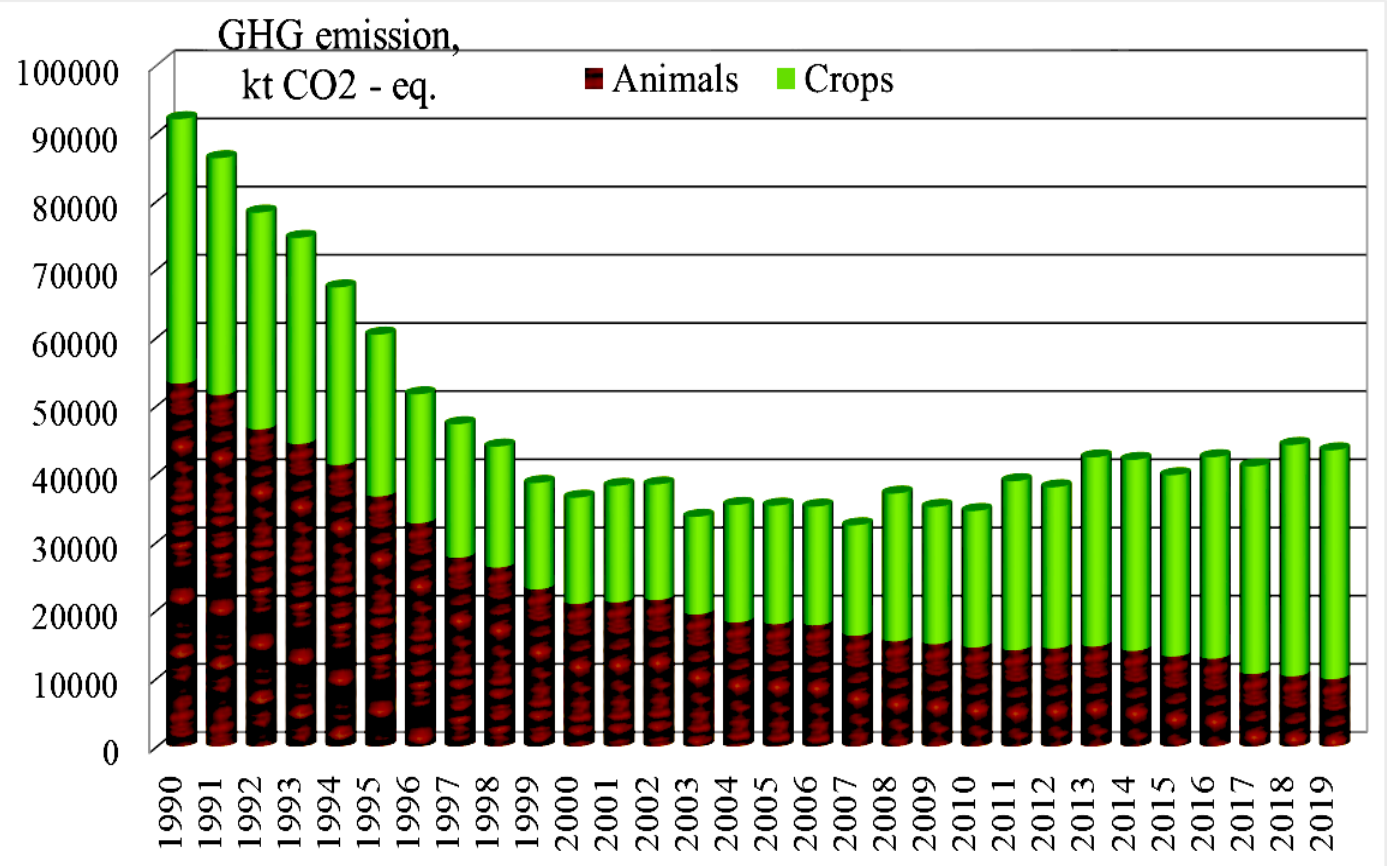

Figure 1. Emission Trends of GHG, kt $\mathrm{CO}_{2}$-eq. 
in particular cattle, which has led to a reduction in emissions under the category "Intestinal fermentation" and, accordingly, under the category "Cleaning, storage and use of manure". In some years, namely during 2000-2002, there was a slight fluctuation in these categories of GHG emissions due to the stabilization of the pig industry due to increasing the volumes of subsidies to the industry.

However, already in 2003, extreme weather conditions (intense cold and a small amount of snow), which led to deep freezing of the land and a significant reduction in forage yields, contributed to a reduction in animal populations and, consequently, to GHG emissions by definite categories.

The transition of agricultural enterprises from liquid manure to solid manure storage also encouraged the reduction of GHG emissions in the category "Cleaning, storage and use of manure". Thus, the percentage of cattle manure stored by agricultural enterprises in liquid systems in 1990 was $21.0 \%$ of the volume of manure produced during the year, and in 2018 - only $5.1 \%$. And since the potential for methane production in liquid manure storage systems is much higher than in its storage in solid form, the volume of emissions for the period 1990-2018 has decreased several times (Ministry of Energy and Environmental Protection of Ukraine, 2020, p.141).

Significantly, in 2018 GHG emissions in the category "Urea application" decreased by $60.7 \%$. It is explained by the decrease in the volume of urea application to agricultural soils. The abandonment of the practice of soil liming has led to a reduction in GHG emissions in the category "Liming" by $94 \%$ compared to 1990 and by 3\% compared to 2018 (Ministry of Energy and Environmental Protection of Ukraine, 2020, p.141).

However, we note that the data of the National Inventory of Anthropogenic Emissions, compiled in accordance with the requirements of the Secretariat of the UN Framework Convention on Climate Change, allow only to state the fact of anthropogenic emissions, without linking them to changes in production, which significantly complicates the formation of clear an idea of the state of the country's transition to lowcarbon production.

We consider it possible to have a realistic assessment of the situation under the condition of introduction of state decoupling audit of low-carbon production, which should be based on uniform methodological principles, the application of which will determine the creation of a system of interconnected analytical data that will reproduce the dynamics and structural changes that occur in production under the influence of investment and innovation factors.

The concept of "decoupling" in domestic practice has not yet been widely used. Interpretations of its substantive component are mainly based on the etymology of the borrowed English term. In particular, on the submission of its content in the Millennium Declaration, approved by the UN General Assembly Resolution of 08.09 .2000 by no. 55 / 2 (Resolution, 2000), in The European Commission proposed a Strategy on the Sustainable Use of Natural Resources used in Europe (The European Commission proposed a Strategy on the Sustainable Use of Natural Resources used in Europe, 2005) of 25.12. 2005. As well as in The Roadmap to a Resource Efficient Europe (2011) (The Roadmap to a Resource Efficient Europe, 2011), where decoupling is seen as a break between the "negative environmental impact" and "economic benefits".

Instead, with the formation of the Assessment of resource efficiency indicators and targets (Final report - 2012) and with the beginning of the UNEP report Decoupling Natural Resource Use and Environmental Impacts from Economic Growth, the concept of "decoupling" has become more broadly interpreted, namely as a key principle related processes of economic growth, the volume of consumed natural resources and environmental pollution, which provides for the growing needs of society while minimizing the load (Tkachenko, et al., 2019). Therefore, the implementation of the decoupling audit will allow us to monitor compliance with the commitments of countries to transition to low-carbon production.

The decoupling audit should be based on the OECD method (OECD, 2001; Zhang, 2020; Zhang, Gu, \& Guo, 2020) for estimating the effect of decoupling by the decoupling index (hereinafter - the Decoupling Index) and the decoupling factor (hereinafter - the Decoupling Factor), which is characterized by the following indicators:

Impact decoupling - decoupling by nature load (the level of impact of the industry or production on the environment);

Resource decoupling - decoupling by natureintensive industry (the level of use of natural resources) (OECD, 2001).

Impact decoupling is determined by the formula:

$$
\text { DecIndex }=(\overline{D F})_{\text {ending }} /\left(\frac{E P}{D F}\right)_{\text {beginning }}=\frac{K_{\text {EPending }}}{K_{\text {DFbeginning }}} \text { (1) }
$$

Where:

DecIndex is decoupling index;

$E P$ - environmental pressure, the indicator of anthropogenic pressure on the environment, natural units;

$D F$ - driving force, an indicator of economic growth, are reflected in gross output, natural units; 
Emission Trends GHG kt CO2-eq emissions by source categories

\begin{tabular}{|c|c|c|c|c|c|c|}
\hline \multirow[b]{2}{*}{ Years } & \multicolumn{6}{|c|}{ GHG source categories in the Agricultural sector of Ukraine } \\
\hline & $\begin{array}{l}\text { A. Enteric } \\
\text { fermentation }\end{array}$ & $\begin{array}{l}\text { B. Manure } \\
\text { management }\end{array}$ & $\begin{array}{l}\text { C. Rice } \\
\text { cultivation }\end{array}$ & $\begin{array}{l}\text { D. Agricultural } \\
\text { soils }\end{array}$ & $\begin{array}{l}\text { G. } \\
\text { Liming }\end{array}$ & $\begin{array}{l}\text { H. Urea } \\
\text { application }\end{array}$ \\
\hline 1990 & 45924,87 & 7308,44 & 216,43 & 35709,95 & 2592,08 & 270,14 \\
\hline 1991 & 44560,91 & 7002,18 & 176,94 & 32979,23 & 1351,26 & 229,79 \\
\hline 1992 & 40442,07 & 6059,95 & 185,58 & 30090,36 & 1351,26 & 189,44 \\
\hline 1993 & 38741,3 & 5618,85 & 176,55 & 28577,34 & 1351,26 & 149,09 \\
\hline 1994 & 36179,91 & 5103,35 & 168,57 & 24426,56 & 1351,26 & 117,71 \\
\hline 1995 & 32063,18 & 4608,23 & 165,17 & 22140,14 & 1351,26 & 86,33 \\
\hline 1996 & 28741,84 & 3998,56 & 172,28 & 18398,56 & 299,2 & 54,95 \\
\hline 1997 & 24479,96 & 3183,73 & 167,36 & 19313,71 & 76,41 & 61 \\
\hline 1998 & 23270,76 & 2977,44 & 154,43 & 17459,45 & 77,79 & 59,96 \\
\hline 1999 & 20270,36 & 2772,65 & 163,47 & 15335,41 & 70,63 & 48,27 \\
\hline 2000 & 18468,6 & 2441,46 & 187,12 & 15264,85 & 63,47 & 82,2 \\
\hline 2001 & 18746,74 & 2399,3 & 140,86 & 16769,07 & 71,47 & 117 \\
\hline 2002 & 18926,94 & 2556,43 & 140,75 & 16647,36 & 53,78 & 116,91 \\
\hline 2003 & 16984,02 & 2372,71 & 166,13 & 13927,54 & 49,37 & 191,1 \\
\hline 2004 & 16016,58 & 2179,28 & 158,16 & 16962,84 & 83,33 & 35,83 \\
\hline 2005 & 15719,51 & 2222,95 & 158,57 & 17011,59 & 90,92 & 138,32 \\
\hline 2006 & 15460,79 & 2314,25 & 161 & 16979,44 & 105,99 & 171,32 \\
\hline 2007 & 13998,08 & 2244,39 & 156,72 & 15731,11 & 112,35 & 212,11 \\
\hline 2008 & 13241,48 & 2187,15 & 146,85 & 21054,47 & 124,95 & 355,18 \\
\hline 2009 & 12767,38 & 2251,1 & 181,97 & 19622,78 & 151,88 & 175,03 \\
\hline 2010 & 12191,9 & 2334,19 & 217,31 & 19348,96 & 127,46 & 334,73 \\
\hline 2011 & 11784,12 & 2317,52 & 219,98 & 24080,83 & 127,16 & 391,52 \\
\hline 2012 & 12016,15 & 2357,81 & 191,74 & 22948,71 & 161,72 & 351,36 \\
\hline 2013 & 12257,78 & 2407,11 & 179,32 & 27008,06 & 182,25 & 381,75 \\
\hline 2014 & 11681,1 & 2344,2 & 75,58 & 27413,42 & 156,26 & 386,03 \\
\hline 2015 & 10970,24 & 2224,99 & 86,7 & 25979,33 & 169,83 & 372,5 \\
\hline 2016 & 10752,01 & 2126,43 & 89,07 & 28876,25 & 140,09 & 457,62 \\
\hline 2017 & 8597,04 & 2022,17 & 94,11 & 29697,25 & 168,6 & 512,07 \\
\hline 2018 & 8298,21 & 2002,73 & 93,58 & 33479,29 & 163,74 & 201,18 \\
\hline 2019 & 7918,02 & 1958,37 & 94,83 & 33004,02 & 163,23 & 316,84 \\
\hline
\end{tabular}

Source: author calculation based on Ministry of Energy and Environmental Protection of Ukraine. 
$K_{E P}, K_{D F}$ - growth rates of relevant indicators.

When assessing the decoupling effect, the values of indicators in the reporting (ending) and base (beginning) periods of the study (years) should be taken into account.

\section{DecFactor $=1-$ DecIndex}

Where:

DecFactor is decoupling factor.

Resource decoupling is calculated by the formula:

DecIndex $=\left(\frac{N}{D F}\right)_{\text {ending }} /\left(\frac{N}{D F}\right)_{\text {beginning }}=\frac{K_{\text {Nending }}}{K_{\text {DFbeginning }}}$

Where:

$\mathrm{N}$ is the amount of used resources of the enterprise or industry, natural units;

$K_{E P}$ - the corresponding growth rate.

To convince of the expediency of introducing a state decapitation audit, we will study the changes in GHG emissions by agribusiness, which according to the National Inventory of Anthropogenic Emissions (Ministry of Energy and Environmental Protection of Ukraine, 2019) entered the TOP-10 leaders in air pollution. In the process of research we will focus on the studied impact and resource decoupling of GHG emissions both in the field of crop production and in the field of animal husbandry for the period from 1990-2019.

For this purpose, to calculate - chain growth rates of GHG emissions in crop production and - chain growth rates of GHG emissions in livestock, we will use the data of the National Inventory of Anthropogenic Emissions (Ministry of Energy and Environmental Protection of Ukraine, 2019), the Draft Annual National Inventory Report for Submission under the United Nations Framework Convention on Climate Change and the Kyoto Protocol for the period 1990-2018 (hereinafter - Annual National) (Ministry of Energy and Environmental Protection of Ukraine, 2020) and data from the State Statistics Service of Ukraine (Prokopenko, 2020).

In this study, GHG in crop production will be carried out in the categories of Rice cultivation, Agricultural soils, Liming, as well as Urea application, and in animal husbandry - by the categories of enteric fermentation and Manure management (Table 1).

Perform single factor analysis of variance (ANOVA) in order to analyze the differences among means in the sample, according to Table 1, the objective of which, in conventional terms, is as follows: to single out three particular variances from the general variance of the parameter:

- The variance determined by the influence of each of the values under consideration;

- The variance dictated by the interconnection between the values under consideration;

- The random variance dictated by all the unconsidered circumstances.

The results of ANOVA are given in Table 2 and 3.

Since the $=119.891$ exceeds the critical level of the F-critical $=2.266$,

Since $\mathrm{F}$ statistics $(F=119.891)$ for the $" \mathrm{GHG}$ source categories» factor, exceeds the critical level $F_{c r i t}=2.266$, this factor does have an impact on the «GHG emissions» parameter under analysis. In other words, we reject the null hypothesis about the equality of means in all classes of factor gradation (groups). Consequently, we conclude that GHG emissions, depending on the sources, differ significantly. This requires an in-depth detailed study by source categories, which is what we will do in animal husbandry - by source categories A and B, and in crop production - by source categories C, D, G and H (unlike research (Tkachenko, et al., 2019).

ANOVA: Single-Factor Summery

Table 2

\begin{tabular}{|l|c|c|c|c|}
\hline $\begin{array}{l}\text { Groups - GHG Source categories in the Agricultural } \\
\text { sector of Ukraine }\end{array}$ & Count & Sum & Average & Variance \\
\hline A. Enteric fermentation & 30 & 601471.9 & 20049.06 & 126319661.1 \\
\hline B. Manure management & 30 & 93897.92 & 3129.93 & 2403263.04 \\
\hline C. Rice cultivation & 30 & 4687.13 & 156.23 & 1562.05 \\
\hline D. Agricultural soils & 30 & 686237.9 & 22874.59 & 41900729.87 \\
\hline G. Liming & 30 & 12340.26 & 411.34 & 386810.03 \\
\hline H. Urea application & 30 & 6567.28 & 218.90 & 18523.98 \\
\hline
\end{tabular}


ANOVA: Single-Factor Report $($ alfa $=0.05)$

Table 3

\begin{tabular}{|l|l|l|l|l|l|l|}
\hline $\begin{array}{l}\text { Source of } \\
\text { Variation }\end{array}$ & $\begin{array}{l}\text { SS (Sum of } \\
\text { Squares) }\end{array}$ & $\begin{array}{l}\text { Df } \\
\text { (Degrees of } \\
\text { Freedom) }\end{array}$ & $\begin{array}{l}\text { MS } \\
\text { (Mean squares) }\end{array}$ & F & P-value & F crit \\
\hline Between Groups & 17087536245 & 5 & 3417507249 & 119.89 & 1.84064 E-54 & 2.266 \\
\hline Within Groups & 4959885953 & 174 & 28505091.7 & & & \\
\hline Total & 22047422198 & 179 & & & & \\
\hline
\end{tabular}

Dynamics of indices of changes in agribusiness during 1990-2019

\begin{tabular}{|c|c|c|c|c|c|c|c|c|}
\hline \multirow{4}{*}{ Years } & \multicolumn{8}{|c|}{ Indices to the previous year, $\%$} \\
\hline & \multicolumn{3}{|c|}{ gross output } & \multirow{3}{*}{ of land } & \multirow{3}{*}{$\begin{array}{l}\text { growth of } \\
\text { animals } \\
\text { and birds }\end{array}$} & \multicolumn{3}{|c|}{ emission trends GHG } \\
\hline & \multirow[b]{2}{*}{$\begin{array}{c}\text { of } \\
\text { agricultural } \\
\text { production }\end{array}$} & \multicolumn{2}{|c|}{ include } & & & \multirow[b]{2}{*}{$\begin{array}{c}\text { agribusiness } \\
\text { of all }\end{array}$} & \multicolumn{2}{|c|}{ include } \\
\hline & & $\begin{array}{l}\text { of crop } \\
\text { production }\end{array}$ & $\begin{array}{c}\text { of animal } \\
\text { production }\end{array}$ & & & & $\begin{array}{l}\text { of crop } \\
\text { production }\end{array}$ & $\begin{array}{l}\text { of animal } \\
\text { production }\end{array}$ \\
\hline 1991 & 86.8 & 83.3 & 90.5 & 99.95 & 96.43 & 93.78 & 89.55 & 96.86 \\
\hline 1992 & 91.7 & 100.1 & 83.5 & 100.34 & 90.53 & 90.75 & 91.59 & 90.18 \\
\hline 1993 & 101.5 & 110.4 & 91.1 & 99.92 & 92.03 & 95.27 & 95.08 & 95.39 \\
\hline 1994 & 83.5 & 77.3 & 92.3 & 99.91 & 87.98 & 90.26 & 86.15 & 93.06 \\
\hline 1995 & 96.4 & 102.6 & 89 & 99.96 & 89.86 & 89.70 & 91.09 & 88.82 \\
\hline 1996 & 90.5 & 91 & 89.7 & 99.94 & 85.74 & 85.51 & 79.70 & 89.28 \\
\hline 1997 & 98.2 & 105.8 & 87.6 & 99.98 & 88.99 & 91.51 & 103.66 & 84.49 \\
\hline 1998 & 90.4 & 83 & 102.8 & 99.92 & 100.84 & 93.05 & 90.48 & 94.88 \\
\hline 1999 & 93.1 & 89.9 & 97.4 & 99.99 & 96.06 & 87.86 & 87.97 & 87.78 \\
\hline 2000 & 109.8 & 121.3 & 95.3 & 99.97 & 90.74 & 94.43 & 99.87 & 90.74 \\
\hline 2001 & 110.2 & 112.3 & 106.8 & 99.95 & 107.36 & 104.75 & 109.62 & 101.12 \\
\hline 2002 & 101.2 & 98.5 & 105.7 & 99.96 & 105.22 & 100.51 & 99.18 & 101.59 \\
\hline 2003 & 89 & 85.9 & 93.9 & 99.96 & 89.64 & 87.64 & 84.52 & 90.1 \\
\hline 2004 & 119.7 & 133.1 & 100.5 & 99.94 & 98.01 & 105.17 & 120.27 & 94 \\
\hline 2005 & 100.1 & 97.5 & 105.1 & 99.89 & 103.21 & 99.73 & 100.92 & 98.6 \\
\hline 2006 & 102.5 & 101.8 & 103.6 & 99.88 & 103.54 & 99.57 & 100.1 & 99.06 \\
\hline 2007 & 93.5 & 90.9 & 98 & 99.94 & 95.40 & 92.21 & 93.07 & 91.37 \\
\hline 2008 & 117.1 & 128.6 & 98.7 & 99.94 & 99.26 & 114.34 & 133.73 & 94.98 \\
\hline
\end{tabular}


Oleksandr Datsii,

Nataliia Levchenko, Ganna Shyshkanova,

Ruslan Dmytrenko, George Abuselidze

State Decoupling Audit of Low-Carbon Agricultural Production

\begin{tabular}{|c|c|c|c|c|c|c|c|c|}
\hline 2009 & 98.2 & 95.3 & 104.2 & 99.92 & 107.3 & 94.71 & 92.85 & 97.34 \\
\hline 2010 & 98.6 & 96.4 & 104.3 & 99.94 & 103.0 & 98.3 & 99.48 & 96.72 \\
\hline 2011 & 120.2 & 128.7 & 99.8 & 99.96 & 96.94 & 112.63 & 123.92 & 97.07 \\
\hline 2012 & 96.1 & 93.3 & 104.9 & 99.95 & 104.86 & 97.7 & 95.3 & 101.93 \\
\hline 2013 & 113.6 & 117.1 & 103.9 & 99.97 & 104.57 & 111.54 & 117.32 & 102.02 \\
\hline 2014 & 102.2 & 103.1 & 99.5 & 99.96 & 90.71 & 99.15 & 101.0 & 95.63 \\
\hline 2015 & 95.2 & 94.8 & 96.4 & 99.98 & 96.01 & 94.64 & 94.92 & 94.08 \\
\hline 2016 & 106.3 & 109.1 & 97.3 & 99.95 & 97.41 & 106.62 & 111.1 & 97.59 \\
\hline 2017 & 97.8 & 97.1 & 100.2 & 99.95 & 97.63 & 96.81 & 103.07 & 82.45 \\
\hline 2018 & 108.2 & 110.2 & 101.2 & 99.62 & 100.14 & 107.65 & 111.37 & 97.0 \\
\hline 2019 & 101.4 & 101.8 & 100.2 & 99.95 & 99.12 & 98.22 & 98.94 & 95.87 \\
\hline
\end{tabular}

We will use the data of chain growth indices for, in our opinion, priority factors of influence to carry out a decoupling audit (Table 4).

The comparison of the dynamics of impact decoupling indicators, namely $K_{E P a}$ and $K_{D F a}$ by the growth rate of gross livestock production is shown in Figure 2a, and according $K_{E P C}$ and $K_{D F_{c}}$ - by the growth rate of gross crop production - in Figure 2b.

We use the classification of decoupling types according to P. Tapio (2015) to describe the decoupling effect, which distinguishes between coupling, decoupling and over coupling (Figure 3).

Coupling effect is observed under the condition of approaching the rates of economic growth to the rates of changes in GHG emissions. At the same time, it can be:

Expansive coupling effect - if the rate of economic growth and GHG emissions tend to increase;

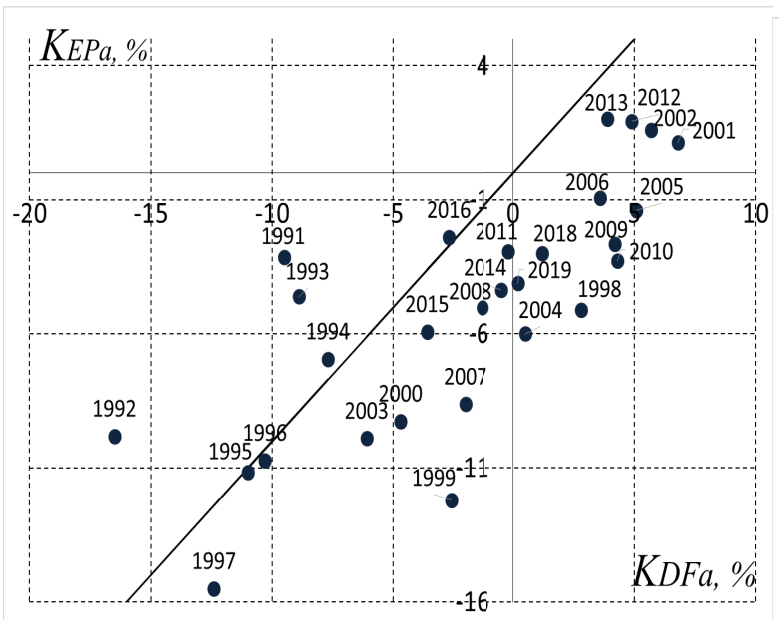

a) animals
Recessive coupling effect - if the rate of economic growth and GHG emissions tend to decrease.

However, in both cases the coupling effect is present only if DecIndex is in the range of $0.8<$ DecIndex $<1.2$.

Decoupling effect is observed in the presence of a gap between the rate of economic growth and the rate of change of GHG emissions. At the same time, it can be:

weak decoupling effect under the condition of simultaneous growth of economic growth rates and GHG emissions, but when the growth rates of the former exceed the latter, i.e. when DecIndex is in the range $0<$ DecIndex $<0.8$;

strong decoupling effect under conditions of growth of economic growth rates and simultaneous decrease in rates of GHG emissions, i.e. when DecIndex is in the range of DecIndex $<0$;

recessive decoupling effect with a simultaneous

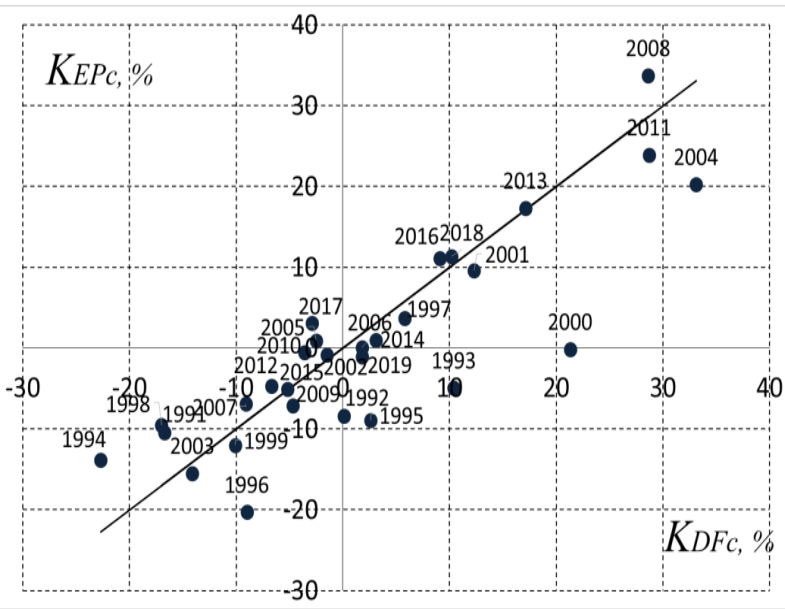

b) crops

Figure 2. Dynamics of growth rates of impact decoupling indicators on agribusiness of Ukraine during 1990-2019. 


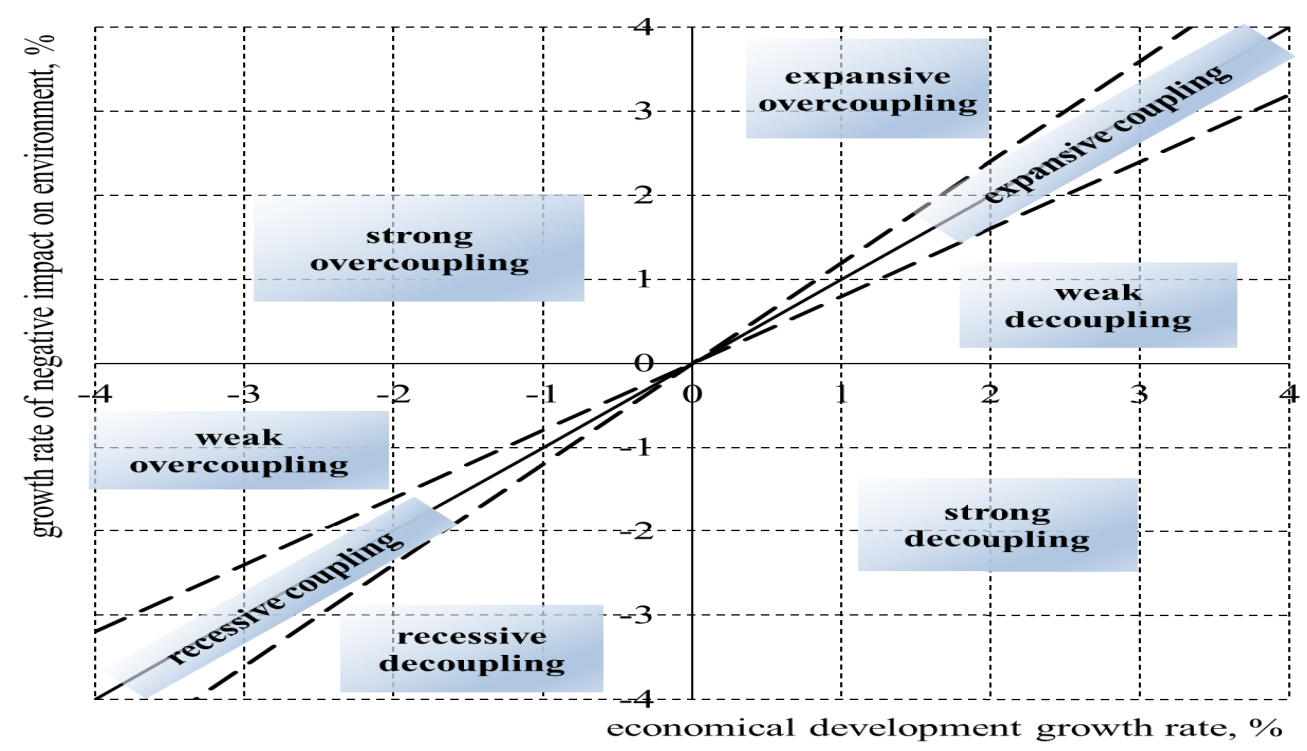

Figure 3. Classification of types of decoupling effect.

decline in economic growth and GHG emissions, but when the rate of decline in GHG emissions exceeds the rate of decline in economic growth, i.e. when DecIndex is in the range of DecIndex $>1.2$;

Overcoupling effect is observed in the negative nature of the gap between economic growth and GHG emissions. It can be:

weak overcoupling effect is observed if the rate of economic growth and the rate of change of GHG emissions tend to decline, but when the rate of decline of economic growth exceeds the rate of decline of GHG emissions, i.e. when DecIndex is in the range $0<$ DecIndex $<0$, 8 ;

strong overcoupling effect is observed if the rate of economic growth tends to decline, and the rate of change in GHG emissions to increase when DecIndex is in the range DecIndex $<0$;

expansive overcoupling effect is observed if the rate of economic growth and the rate of change of GHG emissions tend to increase, but when the growth rate of the latter exceeds the former, i.e. when DecIndex is in the range of DecIndex $>1.2$ (Arsakhanova, Khazhmuradov, \& Khazhmuradova, 2019).

Therefore, according to Figure 2a livestock of the 1990 s is characterized by a weak overcoupling effect, which resulted from a decline in gross output due to a reduction in livestock numbers and negligent treatment of intestinal fermentation, as well as the widespread use of manure as organic fertilizer, accompanied by rising GHG emissions. There has been a steady decline in livestock to this day, but since 1997, the industry has been accompanied by a recessive decoupling effect, which in some years of the first decade of the XXI century gradually transformed into a weak decoupling and strong decoupling effect, which is explained by the gradual increase in gross output due to rising prices and declining GHG emissions due to declining livestock numbers.

It is quite difficult to characterize the phenomenon of decoupling in crop production during the period studied according to Figure $2 \mathrm{~b}$, because significant dependence of gross output on climatic conditions, as well as changes in world prices for grain and other agricultural products, the loss of trade ties with Russia due to military-political conflict in eastern Ukraine, etc. became an obstacle formation of certain trends. Consequently, the decoupling effect during 19902019 in the field of crop production changed quite chaotically. However, the importance of crop production in the total GHG emissions by agribusiness continues to grow every year, which, as noted earlier, is due to the high percentage of arable land in the structure of agricultural land.

Consequently, the decoupling effect during 19902019 in the field of crop production changed quite chaotically. However, the importance of crop production in total GHG emissions by agribusiness continues to grow every year, which, as noted earlier, is due to the high percentage of arable land in the structure of agricultural land.

We will use an integrated approach to assess changes in GHG emissions in agriculture as a whole. The calculation of the integrated impact decoupling of agribusiness in Ukraine during 1990-2019 can be done by $\mathrm{K}_{\mathrm{EPi}}$, determined using the geometric mean value of GHG emission growth indices in livestock and crop production, as well as $\mathrm{K}_{\mathrm{DFi}}$ - chain growth rates of gross output of agribusiness, in \% (Figure 4). 


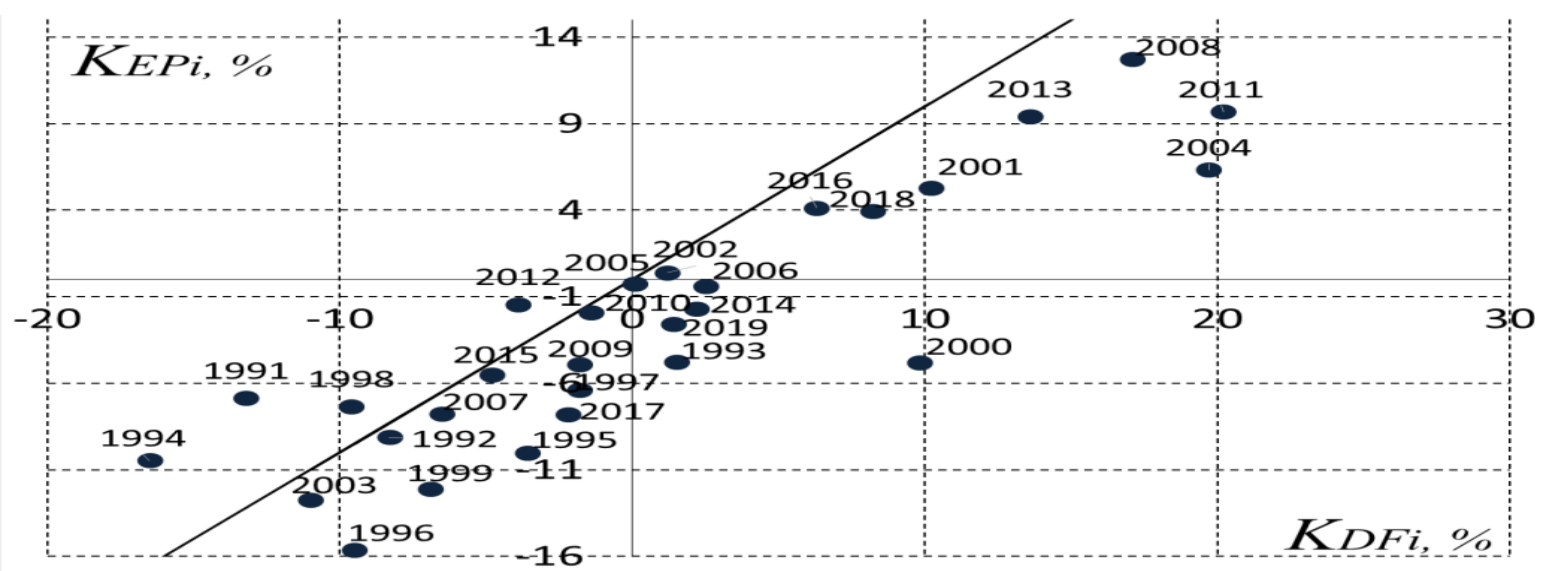

Figure 4. Dynamics of growth rates of integrated impact decoupling in agribusiness of Ukraine during 1990-2019.

The data of Figure 4 convincingly show that the chaos decoupling effect in the field of crop production has left its mark on the decoupling effect on agribusiness in general. However, in the vast majority of years during the period under study, agricultural production is accompanied by a weak decoupling effect, which is gradually transformed into a strong decoupling effect, and vice versa. That is, the level of natural load of agricultural production during 1990-2019 is characterized by certain instability, and therefore, the clarity of the transition of agribusiness in Ukraine to low-carbon production is still not observed.

To convince of the correctness of this statement, we additionally analyse the decoupling effect on resource decoupling indicators, namely by comparing the dynamics of resource decoupling indicators, namely $K_{D F a}$ and $K_{N a}$ the chain growth rate of livestock, the results of which are presented in Figure 5a, and $K_{D F x}$ also $K_{N C}$ and - chain growth rate of agricultural land, the results of which are presented in Figure $5 \mathrm{~b}$. In this case, we will use an integrated approach to determine $K_{N a}$ and calculate with the help of the geometric mean of the growth indices of the number of animals and poultry.

Analysing the data in Figure 5a, we have reason to state that the change in the number of livestock in the vast majority of years during the study period was accompanied by positive changes in the decoupling effect. However, the first years of independence (1991-1997) were quite difficult for livestock, and therefore accompanied by a weak overcoupling effect, as a result of a simultaneous decline in economic growth and the rate of change in GHG emissions in excess of the rate of decline of the latter.

Budget support for the industry, which became more active during 2006-2012, helped to improve the situation in animal husbandry - to increase production volumes while increasing GHG emissions. However,

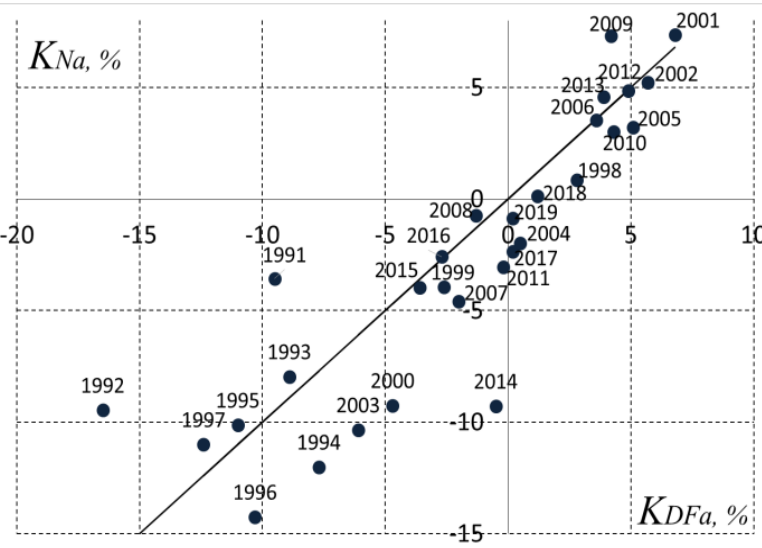

a) animals

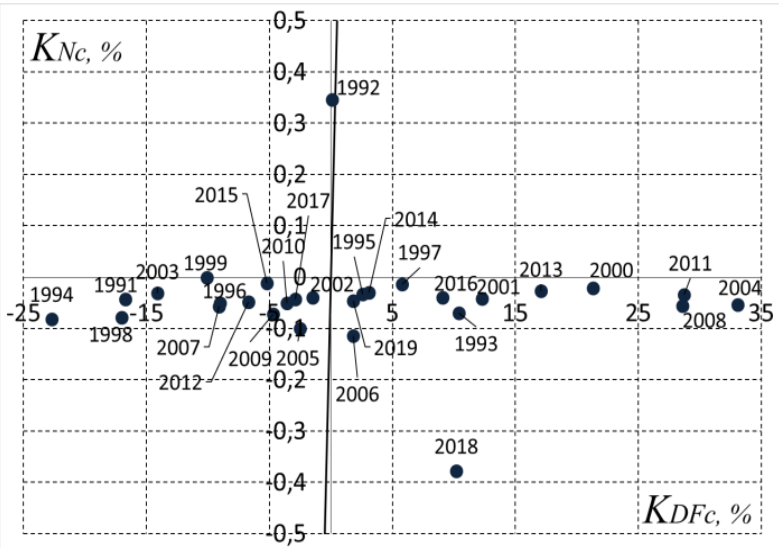

b) crops

Figure 5. Dynamics of growth rates of resource decoupling indicators in agribusiness of Ukraine during 1990-2019. 
the growth rate of the latter over the rate of change in economic growth has led to the expansion of the industry of expansive overcoupling effect.

2015-2016 years were no less difficult. These were the years of difficult epizootic situation, when due to high production costs, declining demand due to changing consumer preferences for the main types of livestock products, low sales prices and limited sales. Thus, most farms in the livestock industry could not reach even the threshold of profitability (break-even), which forced them to further reduce livestock and led to the support of livestock strong overcoupling effect, as a result of declining economic growth against the background of growing GHG emissions.

Studying resource decoupling in crop production, it should be noted that according to Figure 5b during 1990-2019 the industry was accompanied by both the phenomenon of strong decoupling effect and the phenomenon of weak overcoupling effect, which is primarily due to minor changes in agricultural land. Transformation from one to another decoupling effect took place under the influence of natural and climatic conditions, changes in the structure of sown areas, the amount of mineral and organic fertilizers, technologies used for land cultivation, etc.

To determine the integrated resource decoupling in the agribusiness of Ukraine as a whole, by analogy with previous calculations, we use an integrated approach, according to which is determined by the geometric mean of the growth indices of livestock and poultry, as well as - by the geometric mean of the growth indices area of agricultural land (Figure 6).

The obtained calculated values of the decoupling index according to formulas (1) - (3), the dynamics of which is shown in Figures 2, 4-6, are summarized in Table 5.
The data in Table 5 and Figure 6 prove once again that the agribusiness of Ukraine during 1990-2019 was accompanied by a different decoupling effect, which we consider natural, because in agribusiness, as well as in the Ukrainian economy as a whole during the studied period as a result of transformational changes, military and political conflict in eastern Ukraine and other upheavals, there were both recessions and growth. Until then, the expectation of a quick return to the results of the transition of agribusiness to low-carbon production is considered unrealistic.

Of course, the country has set ambitious goals for 2030 and 2050, an anti-carbon policy is formed, an anti-carbon strategy is defined, and, therefore, the only thing is to wait for their implementation. Indicators of resource decoupling in recent years show positive changes, namely the support of agribusiness in 20162018 weak decoupling effect, and in 2019 - strong decoupling effect. Therefore, we believe that in the coming years we will still be able to more clearly observe the transition of domestic agribusiness to low-carbon production. Achieving the ambitious goals set for the period 2030-2050 is known to be possible with the necessary investments to modernize production and implementation of innovative projects.

A correlation and regression analysis was performed for both livestock and crop production to establish the impact of investments on the rate of change in GHG emissions. After smoothing the time series, an optimization selection of nonlinear functional dependences of multifactor regression models was performed. That was done for the greatest correspondence to the initial data. After linearization, the regression coefficients are determined by the generalized least squares method in matrix form:

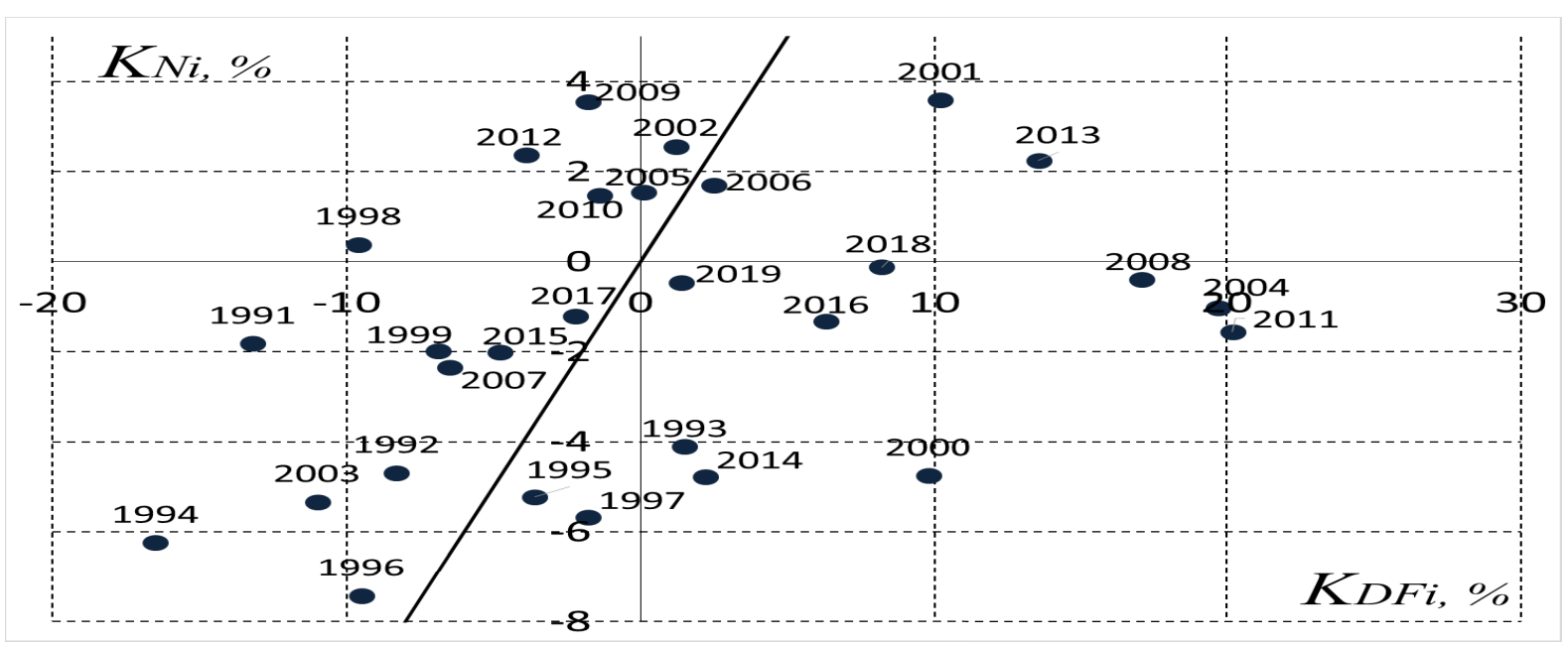

Figure 6. Dynamics of growth rates of integrated resource decoupling in agribusiness in Ukraine during 1990-2019 
The results of the calculation of decoupling indices

Table 5

\begin{tabular}{|c|c|c|c|c|c|c|}
\hline Years & $\begin{array}{l}\text { Impact } \\
\text { DecIndex of } \\
\text { Animal } \\
\text { husbandry }\end{array}$ & $\begin{array}{l}\text { Impact } \\
\text { DecIndex of } \\
\text { Crop } \\
\text { production }\end{array}$ & $\begin{array}{l}\text { Integral Impact } \\
\text { DecIndex of } \\
\text { agribusiness }\end{array}$ & $\begin{array}{l}\text { Recourse } \\
\text { DecIndex of } \\
\text { Animal } \\
\text { husbandry }\end{array}$ & $\begin{array}{l}\text { Recourse } \\
\text { DecIndex of } \\
\text { Crop } \\
\text { production }\end{array}$ & $\begin{array}{l}\text { Integral } \\
\text { Recourse } \\
\text { DecIndex of } \\
\text { agribusiness }\end{array}$ \\
\hline 1991 & 0.33 & 0.62 & 0.519 & 0.375 & 0.002 & 0.137 \\
\hline 1992 & 0.59 & -84.07 & 1.098 & 0.573 & 3.457 & 0.564 \\
\hline 1993 & 0.51 & -0.47 & -3.172 & 0.895 & -0.006 & -2.732 \\
\hline 1994 & 0.90 & 0.61 & 0.633 & 1.560 & 0.003 & 0.378 \\
\hline 1995 & 1.015 & -3.42 & 2.790 & 0.921 & -0.012 & 1.450 \\
\hline 1996 & 1.04 & 2.25 & 1.646 & 1.384 & 0.005 & 0.781 \\
\hline 1997 & 1.25 & 0.63 & 3.561 & 0.887 & -0.002 & 3.150 \\
\hline 1998 & -1.82 & 0.56 & 0.764 & 0.301 & 0.004 & -0.039 \\
\hline 1999 & 4.69 & 1.19 & 1.755 & 1.513 & 0.0001 & 0.288 \\
\hline 2000 & 1.96 & -0.006 & -0.490 & 1.969 & -0.001 & -0.484 \\
\hline 2001 & 0.16 & 0.782 & 0.518 & 1.083 & -0.003 & 0.352 \\
\hline 2002 & 0.27 & 0.544 & 0.318 & 0.916 & 0.026 & 2.132 \\
\hline 2003 & 1.62 & 1.097 & 1.157 & 1.697 & 0.002 & 0.484 \\
\hline 2004 & -11.99 & 0.612 & 0.321 & -3.965 & -0.001 & -0.051 \\
\hline 2005 & -0.27 & -0.369 & -2.412 & 0.631 & 0.040 & 15.451 \\
\hline 2006 & -0.25 & 0.058 & -0.166 & 0.983 & -0.063 & 0.678 \\
\hline 2007 & 4.31 & 0.760 & 1.196 & 2.297 & 0.006 & 0.362 \\
\hline 2008 & 3.85 & 1.179 & 0.743 & 0.562 & -0.002 & -0.023 \\
\hline 2009 & -0.63 & 1.520 & 2.738 & 1.738 & 0.015 & -1.971 \\
\hline 2010 & -0.76 & 0.142 & 1.361 & 0.699 & 0.014 & -1.047 \\
\hline 2011 & 14.61 & 0.833 & 0.479 & 15.257 & -0.001 & -0.077 \\
\hline 2012 & 0.39 & 0.701 & 0.369 & 0.991 & 0.007 & -0.609 \\
\hline 2013 & 0.52 & 1.013 & 0.691 & 1.172 & -0.001 & 0.165 \\
\hline 2014 & 8.72 & 0.325 & -0.778 & 18.575 & -0.009 & -2.168 \\
\hline 2015 & 1.64 & 0.976 & 1.145 & 1.106 & 0.002 & 0.420 \\
\hline 2016 & 0.89 & 1.220 & 0.656 & 0.958 & -0.004 & -0.209 \\
\hline 2017 & -87.71 & -1.060 & 3.549 & -11.806 & 0.015 & 0.549 \\
\hline 2018 & -2.49 & 1.115 & 0.480 & 0.117 & -0.037 & -0.014 \\
\hline 2019 & -20.61 & -0.587 & -1.858 & -4.362 & -0.026 & -0.329 \\
\hline
\end{tabular}




\section{Where:}

$$
\begin{aligned}
& E a=-16178.642+\frac{127955.206}{I a^{0.4}}+\frac{34109.784}{S a^{0.2}}+83.823 \cdot V a^{0.4} \\
& E c=-11837.504+\frac{58526.761}{I c^{0.2}}+\frac{65690.912}{S c^{0.5}}+43.902 \cdot V c^{0.5}
\end{aligned}
$$

$E_{a} ; E_{c}$ are volumes of GHG emissions into the atmosphere (GHG) from livestock and crop production correspondently, $\mathrm{CO}_{2}-$ eq. thousand tons,

$I_{a} ; I_{c}$ are capital investments in animal husbandry and crop production, UAH million

$S_{a} ; S_{c}$ are current costs for environmental protection in animal husbandry and crop production, UAH million
$V_{a} ; V_{c}$ are volumes of gross livestock and crop production, UAH million

The calculated values of the Fisher's coefficients $F_{I}=21.22, F_{2}=34.76$, and the critical level $F_{c r}=2.98$ for the degrees of freedom $k_{1}=3, k_{2}=26$ and level of significance $\alpha=0,05$. Thus, Fisher's test, $F_{1,2}>F_{c r}$, showed that with $95 \%$ reliability we can assume that the proposed mathematical models are adequate to the statistic data and on the basis of the adopted models it is possible to evaluate the effectiveness of the coordination mechanism of agribusiness to low carbon production.

Graphs of the model (4) are shown in Figure 7a for

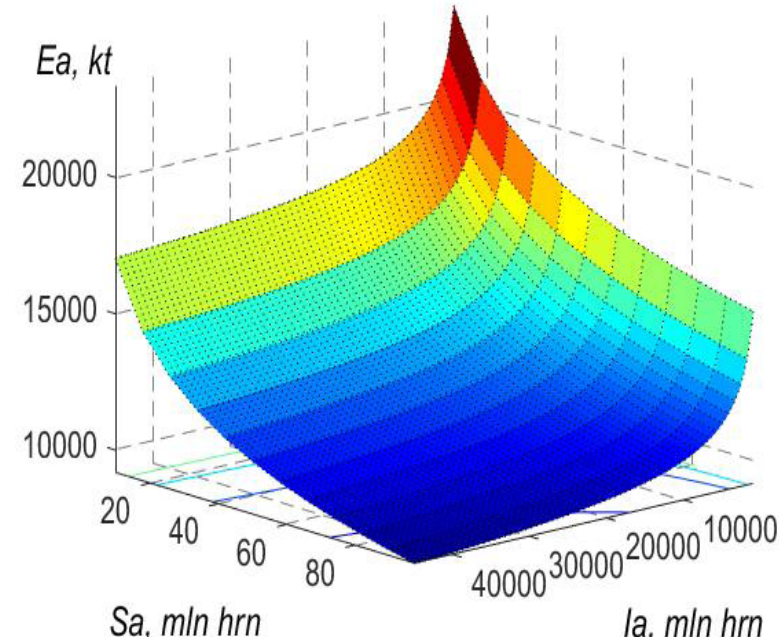

a) environmental costs

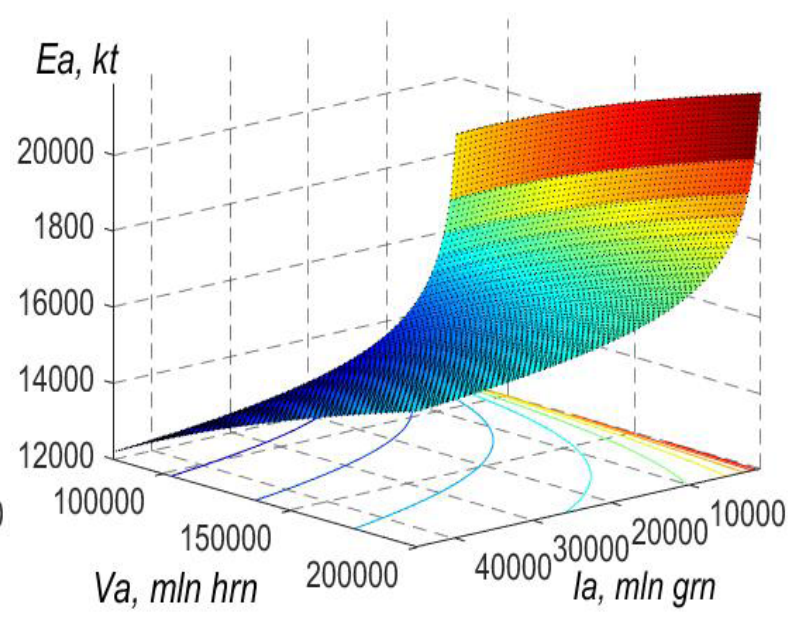

b) volumes of gross output

Figure 7. Dependence of livestock GHG emissions on capital investment in livestock agribusiness modernization

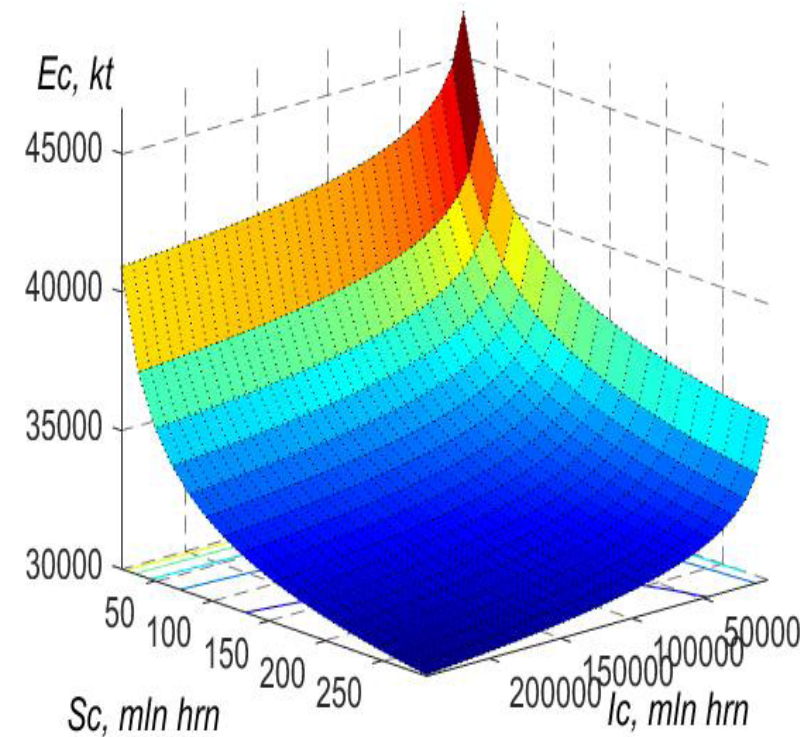

a) environmental costs

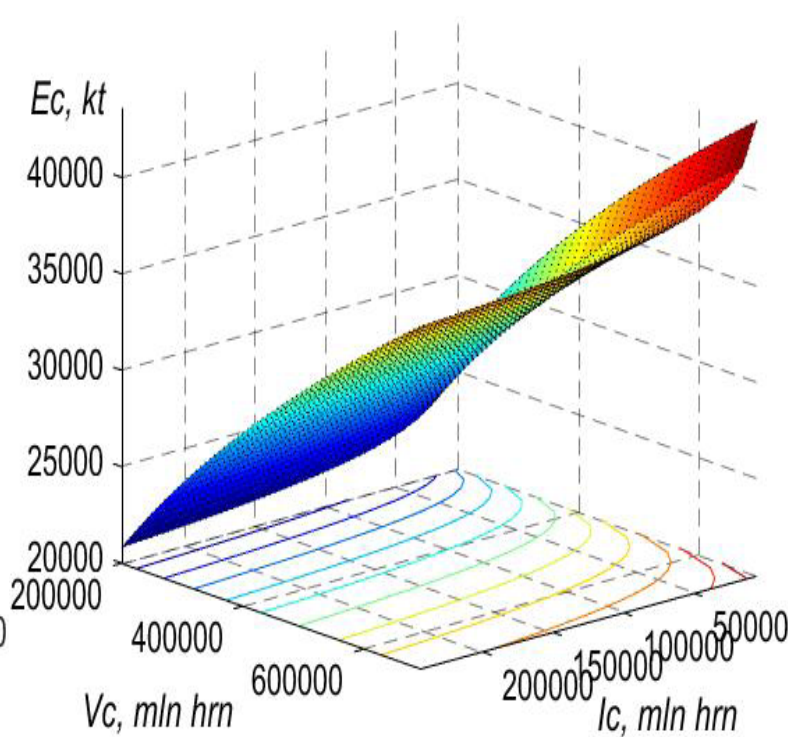

b) volumes of gross output

Figure 8. Dependence of crop production GHG emissions on capital investment in crop agribusiness modernization. 
Results of modelling GHG emission scenarios for the second Nationally Determined Contribution of Ukraine to the Paris Agreement

\begin{tabular}{|l|c|c|c|c|c|c|}
\hline \multirow{2}{*}{ Scenarios } & \multicolumn{2}{|c|}{$\begin{array}{c}\text { Indices of GHG } \\
\text { emission reductions in } \\
\text { agribusiness compared } \\
\text { to } 1990, \%\end{array}$} & $\begin{array}{c}\text { Indices of growth of needs for } \\
\text { capital investments in } \\
\text { agribusiness relative to 2018, } \\
\%\end{array}$ & $\begin{array}{c}\text { Growth indices of } \\
\text { gross agribusiness } \\
\text { production relative to } \\
2018, \%\end{array}$ \\
\cline { 2 - 7 } & 2030 & 2050 & 2030 & 2050 & 2030 & 2050 \\
\hline 1. BAU Scenario & 48 & 48 & 120 & 152 & 107.8 & 120.7 \\
\hline 2. Reference Scenario & 46 & 44 & 156 & 176 & 111.2 & 127.8 \\
\hline $\begin{array}{l}\text { 3. Scenario of climate- } \\
\text { neutral economy }\end{array}$ & 44 & 40 & 172 & 370 & 117.6 & 131.2 \\
\hline
\end{tabular}

the constant value of $\mathrm{Va}=153018.3$ million $\mathrm{UAH}$ and in Figure $7 \mathrm{~b}$ for the constant value of $\mathrm{Sa}=18.9$ million UAH.

Graphs of the model (5) are shown in Figure 8a for the constant value of $\mathrm{Vc}=570636.6$ million $\mathrm{UAH}$ and for the constant value of $\mathrm{Sc}=65.1$ million $\mathrm{UAH}$ in Figure $8 b$.

The images in Figures 7 and 8 convincingly show that with increasing capital investment and current expenditures on environmental protection, GHG emissions are declining. However, it should be remembered that as the food security problem worsens, the world expects Ukraine, as one of the leaders in the export of agricultural products, to increase production volumes, which will lead to an increase in GHG emissions. Therefore, when determining the liabilities for the second and subsequent nationally determined contributions to the Paris Agreement, it is necessary to take into account (United Nations, 2015) the dependence of GHG emissions on the volume of gross output.

Thus, the Institute of Economics and Forecasting of the National Academy of Sciences of Ukraine within the EBRD Project "Support to the Government of Ukraine to update the nationally determined contribution" has developed models of GHG emissions in different economic scenarios (The Institute for Economics and Forecasting, NASU, 2020), the results of which for agribusiness are given in Table 6 .

Forecasts for scenario 1 (baseline scenario) were based on past and current trends in agribusiness (The Institute for Economics and Forecasting, NASU, 2020 , p.72), as well as on the current level of implementation of current legislation - its implementation only partially or with a significant delay (The Institute for Economics and Forecasting, NASU, 2020, p.6). According to this scenario, in the sector "Agriculture" it is expected that in 2030 the volume of GHG emissions will be $52 \%$ lower than the volume of emissions in 1990 (The Institute for Economics and Forecasting, NASU, 2020, p.13).

At the same time, according to Scenario 2 (reference scenario), GHG emissions in this sector are expected to be about twice as low as in 1990, but about $7 \%$ higher than at the current level. In particular, the category "Intestinal fermentation" according to certain forecasts provides for a reduction in GHG emissions from internal fermentation to $20 \%$ from 1990 levels. A similar trend will occur in the category of "The handling of manure". Emissions from this category of GHG emission sources are expected at $30 \%$ of 1990 levels, due to a decrease in livestock compared to the base year, as well as an increase in the use of manure biogas plants and the use of additional substances in the diet of animals (The Institute for Economics and Forecasting, NASU, 2020, p.72).

Regarding the forecasts of GHG emissions from agricultural lands, it should be noted that in the coming years they are expected to increase due to the increase in arable land. However, they are projected to be lower than in the base year. Achieving the reduction of GHG emissions from agricultural land is expected by reducing the level of mineralization of agricultural soils, as well as the spread of new technologies in crop production, in particular, tillage with reduced reservoir turnover (or no turnover), which will reduce GHG emissions in the area up to 5 million hectares (The Institute for Economics and Forecasting, NASU, 2020, p.73).

Emissions in this sector until 2030 are projected to be similar to the trends and processes as in Scenario 1, but Scenario 2 includes full implementation of national anti-carbon policy and implementation of strategies such as "Low Carbon Development Strategy of Ukraine until 2050" (Handrich; A low carbon development strategy for Ukraine until 2050; 
Table 7

Forecasts of expected GHG emissions by crop production in 2030 and in 2050 under the EBRD Project

\begin{tabular}{|l|c|c|c|c|c|c|}
\hline \multirow{2}{*}{\multicolumn{1}{|}{ Indicators }} & \multicolumn{3}{|c|}{2030 year } & \multicolumn{3}{c|}{2050 year } \\
\cline { 2 - 7 } & I Scenario & II Scenario & III Scenario & I Scenario & II Scenario & III Scenario \\
\hline$I c$, million UAH & 64952.9 & 84438.7 & 93099.1 & 82273.6 & 95264.2 & 200271.4 \\
\hline$S c$, million UAH & 65.1 & 84.7 & 93.4 & 82.5 & 95.6 & 200.8 \\
\hline$V c$, million UAH & 570636.6 & 588634.4 & 622512.7 & 638922.4 & 676506.1 & 694503.9 \\
\hline $\begin{array}{l}E c \text { in } \mathrm{CO}_{2} \text { - eq. } \\
\text { thousand tons }\end{array}$ & 18618.5 & 17842.8 & 17066.9 & 18618.5 & 17066.9 & 15515.4 \\
\hline
\end{tabular}

Eyl-Mazzega, \& Mathieu, 2019), "State Environmental Strategy by 2030" and others (The Institute for Economics and Forecasting, NASU, 2020, p.72).

Thus, according to Scenario 2 in the sector "Agriculture" for all categories of sources, it is expected to reduce GHG emissions in 2030 to $49 \%$ of 1990 levels and in 2050 - to $47 \%$ of 1990 levels (The Institute for Economics and Forecasting, NASU, 2020, p.75).

Forecasts under Scenario 3 (climate-neutral economy scenario) are based on the implementation of all measures identified in Scenario 2 and larger-scale implementation of advanced technologies that are not currently used in agribusiness due to the need for significant investment and lack of knowledge (The Institute for Economics and Forecasting, NASU, 2020, p.73).

Therefore, it is expected that GHG emissions in 2030 will be $47 \%$ of the 1990 level and in $2050-42 \%$ of the 1990 level (The Institute for Economics and Forecasting, NASU, 2020, p.75). Thus, the forecasts of expected emissions in crop and livestock production in 2030 and in 2050 in terms of natural units are characterized by the data given in Table 7 and 8 .
For the crop sector, by 2030, Scenarios 2 and 3 envisage an increase in both capital investment and current expenditures on environmental protection, which is almost $1 / 3$ higher than in 2018. At the same time, a slight increase in gross output is expected (up to $5 \%$ of the 2018 level) at a similar level of reduction of GHG emissions, which will provide support for this industry of weak decoupling-effect.

Scenario 2 until 2050 expects almost similar results as Scenario 3 until 2030. However, the deepening climate crisis requires more radical action to reduce GHG emissions. Therefore, Scenario 3 envisages an increase in capital investment and current environmental costs by almost three times by 2050 compared to their level in 2018. At the same time, the gross output is expected to increase to 694.503.9 million UAH, i.e. up to $10 \%$ from 2018 while reducing GHG emissions by more than $15 \%$ from 2018 , which will provide support for this industry of strong decoupling effect.

Reduction of GHG emissions in the livestock sector is expected in the same way as in crop production, due to increased capital investment and

Table 8

Forecasts of expected GHG emissions by livestock in 2030 and 2050 according to the EBRD Project

\begin{tabular}{|l|c|c|c|c|c|c|}
\hline \multirow{2}{*}{\multicolumn{1}{|c|}{ Indicators }} & \multicolumn{3}{|c|}{2030 year } & \multicolumn{3}{c|}{2050 year } \\
\cline { 2 - 7 } & $\begin{array}{c}\text { I } \\
\text { Scenario }\end{array}$ & $\begin{array}{c}\text { II } \\
\text { Scenario }\end{array}$ & $\begin{array}{c}\text { III } \\
\text { Scenario }\end{array}$ & $\begin{array}{c}\text { I } \\
\text { Scenario }\end{array}$ & $\begin{array}{c}\text { II } \\
\text { Scenario }\end{array}$ & $\begin{array}{c}\text { III } \\
\text { Scenario }\end{array}$ \\
\hline Ic, million UAH & 13117.9 & 17053.3 & 18802.4 & 16616.0 & 19239.6 & 40446.9 \\
\hline$S c$, million UAH & 18.9 & 24.7 & 27.2 & 24.0 & 27.8 & 58.5 \\
\hline$V c$, million UAH & 153018.3 & 157844.5 & 166929.1 & 171329.4 & 181407.6 & 186233.8 \\
\hline $\begin{array}{l}\text { Ec in } \mathrm{CO}_{2} \text { - eq. } \\
\text { thousand tons }\end{array}$ & 25551.9 & 24487.3 & 23422.7 & 25551.9 & 23422.7 & 21293.3 \\
\hline
\end{tabular}




\section{Comparative analysis of forecasts of expected GHG emissions by agribusiness in 2030 and 2050 according to the EBRD Project and the author's methodology}

\begin{tabular}{|l|c|c|c|c|c|c|}
\hline \multirow{2}{*}{\multicolumn{1}{|c|}{ Indicators }} & \multicolumn{3}{c|}{2030 year } & \multicolumn{2}{c|}{2050 year } \\
\cline { 2 - 7 } & $\begin{array}{c}\text { I } \\
\text { Scenario }\end{array}$ & $\begin{array}{c}\text { II } \\
\text { Scenario }\end{array}$ & $\begin{array}{c}\text { III } \\
\text { Scenario }\end{array}$ & $\begin{array}{c}\text { I } \\
\text { Scenario }\end{array}$ & $\begin{array}{c}\text { II } \\
\text { Scenario }\end{array}$ & $\begin{array}{c}\text { III } \\
\text { Scenario }\end{array}$ \\
\hline $\begin{array}{l}\text { GHG emissions under the } \\
\text { EBRD Project }\end{array}$ & $44,170.52$ & $42,330.08$ & $40,489.64$ & $44,170.52$ & $40,489.64$ & $36,808.76$ \\
\hline $\begin{array}{l}\text { GHG emissions according to } \\
\text { the author's method, total }\end{array}$ & $42,730.31$ & $40,845.4$ & $41,001.29$ & $42,561.64$ & 42.353 .94 & $37,246.63$ \\
\hline $\begin{array}{l}\text { including: } \\
\text { in crop production }\end{array}$ & $35,845.62$ & $35,037.81$ & $35,536.37$ & $36,571.98$ & 36.902 .4 & $34,478.15$ \\
\hline in animal husbandry & $6,884.692$ & $5,807.593$ & $5,464.923$ & $5,989.667$ & $5,451.53$ & $2,768.478$ \\
\hline
\end{tabular}

current environmental costs by almost $1 / 3$ and the implementation of technologies for biogas production from manure, which will not only replace fossil fuels for energy goals, but also to reduce the level of GHG emissions from manure by $10 \%$ by 2030 (see Table 8 ) (The Institute for Economics and Forecasting, NASU, 2020, p.73).

At the same time, the implementation of technologies for biogas production from manure in the livestock sector according to Scenario 3 will not only replace fossil fuels for energy purposes, but also reduce GHG emissions by $50 \%$ by 2050 (The Institute for Economics and Forecasting, NASU, 2020, p.74). However, it should be recognized that Scenario 3 compared to others is more aggressive to changes in capital investment and current costs of environmental protection and provides for their increase compared to 2018 almost three times, i.e. up to 40446.9 million UAH and 58.5 million UAH in accordance.

If we summarize the required level of investment by year and estimate the difference between Scenarios 2 and 3, we can conclude that the level of investment in both crop and livestock will differ slightly by 2035 . And only, starting from 2035 onwards, the level of required investments under Scenario 3 should be higher than under Scenario 2, mainly due to assumptions of rising prices for new technologies (The Institute for Economics and Forecasting, NASU, 2020, p.11). At the same time, the expected GHG emissions made by the forecasts within the framework of the EBRD Project are characterized by the data presented in Table 9.

However, the forecast calculations according to the proposed author's model show that the forecast calculations made by the Institute of Economics and Forecasting of the National Academy of Sciences of
Ukraine within (The Institute for Economics and Forecasting, NASU, 2020) are not realistic enough and will not provide the expected results in the future.

Our projected values exceed the indicators to be pursued under Scenario 3 by 2030 and, most importantly, in relation to Scenarios 2 and 3 by 2050 . The simulation results showed that the identified amounts of capital investment and current environmental costs are insufficient to achieve ambitious goals, defined by the anti-carbon strategy of Ukraine and will not ensure the achievement, determined by the conclusions of the IPCC (Intergovernmental Panel on Climate Change), of the desired emission trajectory to curb global warming on the planet not higher than $1.5^{\circ} \mathrm{C}$ until 2030 and 2050 .

This confirms that in the near future the focus on the full implementation of the anti-carbon policy of the Government of Ukraine and the planned measures is critical. Therefore, there is an urgent need to review capital investment in new innovative technologies, which are expected to become commercially available after 2030 and allow Ukraine to increase the level of ambition of its goals in the long run. Full implementation of existing strategies according to Scenario 2 and extrapolation of relevant targets by 2050 is an ambitious task itself and will require a multiple increase in investment in the agricultural sector to volumes comparable to the best examples of countries whose economies are developing rapidly.

Meanwhile, even such a long-term extension of policies with the current level of ambition will not be enough to stabilize GHG emissions, the level of which according Scenario 2 begins to grow moderately after 2035. Although Scenarios 2 and 3 are in fact superimposed on each other by 2030 and can only provide some information in the process of preparation 
Forecasts of expected GHG emissions by agribusiness in 2030 and in 2050 with increased capital investment

\begin{tabular}{|l|c|c|c|c|c|c|}
\hline \multirow{2}{*}{\multicolumn{1}{|c|}{ Indicators }} & \multicolumn{3}{|c|}{2030 year } & \multicolumn{3}{c|}{2050 year } \\
\cline { 2 - 7 } & $\begin{array}{c}\text { I } \\
\text { Scenario }\end{array}$ & $\begin{array}{c}\text { II } \\
\text { Scenario }\end{array}$ & $\begin{array}{c}\text { III } \\
\text { Scenario }\end{array}$ & $\begin{array}{c}\text { I } \\
\text { Scenario }\end{array}$ & $\begin{array}{c}\text { II } \\
\text { Scenario }\end{array}$ & $\begin{array}{c}\text { III } \\
\text { Scenario }\end{array}$ \\
\hline $\begin{array}{l}\text { GHG emissions } \\
\text { according to the } \\
\text { author's method, total }\end{array}$ & $41,611.59$ & $40,044.15$ & $40,294.09$ & $41,733.37$ & $41,667.25$ & $36,982.93$ \\
\hline $\begin{array}{l}\text { including: } \\
\text { in crop production }\end{array}$ & $35,231.62$ & $34,607.4$ & $35,159.56$ & $36,126.1$ & $36,537.24$ & $34,346.64$ \\
\hline in animal husbandry & $6,379.976$ & $5,436.746$ & $5,134.522$ & $5,607.276$ & $5,130.017$ & $2,636.289$ \\
\hline
\end{tabular}

of the $2^{\text {nd }}$ National-Defined Contribution of Ukraine to the Paris Agreement (United Nations, 2015), in the long run the dynamics of GHG emissions under these scenarios significantly differs, which highlights the need for further analysis (The Institute for Economics and Forecasting, NASU, 2020, p.103).

According to the projected calculations of the author's method for Ukraine's transition to low-carbon production, capital investment in the agricultural sector of the economy should be increased by at least $15 \%$ compared to their volume projected until 2050 under Scenario 3, which will reduce GHG emissions accordingly to the ambitious goals set by the anticarbon policy of Ukraine and the Strategy of lowcarbon development of Ukraine until 2050. Given the increase in capital investment, the expected GHG emissions in agribusiness as a whole and in crop production and animal husbandry will be characterized by the forecasts presented in Table 10 .

Forecasts of GHG emissions by the crop industry are many times higher than GHG emissions by the livestock industry. With a constant area of agricultural land, namely the area of arable land, it is possible to reduce emissions in crop production due to the expansion of organic production and the wider use of technologies for minimal tillage.

Organic production, combining high quality standards and best environmental practices, contributes to both the conservation of natural resources and biodiversity, and the reduction of GHG emissions. According to research conducted within the project "Assessment of technological needs in Ukraine", organic production can occupy up to 4 million hectares. Currently, the area under organic production is only 309 thousand hectares and therefore, domestic agribusiness has significant potential for its implementation. At the same time, the potential for the introduction of technologies of minimum tillage, according to the same study, can reach 10 million hectares (European Green Deal, 2020).

In order to create the necessary information support for the decoupling audit, we consider it expedient to supplement the GRI 300 "Environmental Disclosures" (The Global Reporting Initiative 300, 2017), which are currently being adapted, with the group of indicators GRI-305.5 "Reduction of GHG emissions" in the preparation of the second National Determined Contribution to the Paris Agreement, formed by the decoupling approach, which will ensure control over compliance with the commitments made by each of the enterprises, and hence by each industry and country to implement the transition to low-carbon production.

\section{Conclusions}

Thus, the study found that the strategic focus of transformational changes in the economy is currently chosen low-carbon production, the achievement of which is possible with the consistent application of an arsenal of strict control measures, in particular, the introduction of state decoupling audit of low-carbon production, which will ensure the formation according to the decoupling approach of the most realistic portfolio of the state of transition of a particular industry to low-carbon production.

The author's economic and mathematical models of estimation according to the decoupling approach of the influence of crop and livestock industries on atmospheric pollution are offered. A comparative analysis of forecasts of changes in GHG emissions with increasing gross output of agricultural production, defined by the Institute of Economics and Forecasting of the NAS of Ukraine in different scenarios of economic development with forecasts determined by 
the author's method and identified by the results of GAP-analysis ways to achieve the ambitious goals set by the Low Carbon Development Strategy of Ukraine until 2050.

The expediency of supplementing the GRI 300 "Environmental Disclosures" (The Global Reporting Initiative 300, 2017) in the framework of the preparation of the second National Determined Contribution to the Paris Agreement has been substantiated. They are currently in the process of adapting a set of indicators to the GRI-305.5 "Reduction of GHG emissions", which will ensure compliance with the commitments made by each of the enterprises to implement the transition to low-carbon production.

\section{References}

Abuselidze, G. (2019). Modern Challenges of Monetary Policy Strategies: Inflation and Devaluation Influence on Economic Development of the Country. Academy of Strategic Management Journal. 18(4), 1-10.

Abuselidze, G., \& Kizinidze, M. (2019). Influence of central bank regulations on interbank competition in association with EU. E3S Web of Conferences. 135, 04037. DOI: 10.1051/e3sconf/201913504037

Abuselidze, G. (2021). The Impact of Banking Competition on Economic Growth and Financial Stability: An Empirical Investigation. European Journal of Sustainable Development. 10(1), 203-220. DOI: 10.14207/ejsd.2021.v10n1p203

Abuselidze, G. (2021). Use of hedging instruments on the example of the grain market. 20th International Scientific Conference Engineering for Rural Development Proceedings. DOI: 10.22616/ERDev.2021.20.tf359

About the Basic principles (strategy) of the state environmental policy of Ukraine for the period till 2030. Law of Ukraine No. 2697-VIII. 28 February, 2019, from http://cis-legislation.com/ document.fwx?rgn=115073

A low carbon development strategy for Ukraine until 2050, 1-79, from http://mepr.gov.ua/files/docs/ Proekt/LEDS_ua_last.pdf

Arsakhanova, Z. A., Khazhmuradov, Z. D., \& Khazhmuradova, S. D. (2019). Decapling in the economy - Essence, Definition and Types. Society, Economy, Management. 4, 13-18.

Campiglio, E. (2016). Beyond carbon pricing: The role of banking and monetary policy in financing the transition to a low-carbon economy. Ecological Economics. 121, 220-230. DOI: 10.1016/ j.ecolecon.2015.03.020

Carraro, C., Favero, A., \& Massetti, E. (2012). Investments and public finance in a green, low carbon, economy. Energy Economics. 34(1),
S15-S28. DOI: 10.1016/j.eneco.2012.08.036

Climate Commitments Not On Track to Meet Paris Agreement Goals, as NDC Synthesis Report is Published. (UNEP press release, 2021), from http:/unfecc.int/news/climate-commitmentsnot-on-track-to-meet-paris-agreement-goalsas-ndc-synthesis-report-is-published

Environmental Strategy for the First Decade of the 21st Century. (OECD, 2001), from http:// www.oecd.org/env/indicators-modellingoutlooks/1863539.pdf

European Green Deal. (2020). Opportunities and Threats to Ukraine, 1-74, from http://www.irf.ua/ wp-content/uploads/2020/09/web_europeangreen-deal_2020_en.pdf

Eyl-Mazzega, M. A., \& Mathieu, C. (2019). Developing a National Energy and Climate Plan for Ukraine: Key Objectives, Strategic Questions and Options, 1-17, Berlin Economics, from http:// www.lowcarbonukraine.com/wp-content/ uploads/LCU_PP02_2019-03_en.pdf

Foxon, T. J. (2011). A coevolutionary framework for analysing a transition to a sustainable low carbon economy. Ecological economics. 70(12), 22582267. DOI: $10.1016 /$ j.ecolecon.2011.07.014

Hahnel, R. (2014). Green Economics: Confronting the Ecological Crisis: Confronting the Ecological Crisis. Routledge. DOI: 10.4324/9781315703947

Haidutsky, I. P. (2017). Niz'kovuglecevij rozvitok: global'ni instrumenti motivaciï investiciï: praktika i opyt (Low-Carbon Development: Global Tools for investment motivation: practice and experience). 2, 22-26. (in Ukrainian)

Handrich, L. Concept of a low carbon development strategy for Ukraine, 1-49, from http://diw-econ.de/ wp-content/uploads/LCD_Strategy-for-UA_v1-0.pdf

Ji, Z., Abuselidze, G., \& Lymar, V. (2021). Problems and perspectives of sustainable trade development in China under the one belt one road initiative. E3S Web of Conferences. 258, 06050. DOI: $10.1051 / \mathrm{e} 3$ sconf $/ 202125806050$

Liu, X., Kwon, H., Northrup, D., \& Wang, M. (2020). Shifting agricultural practices to produce sustainable, low carbon intensity feedstocks for biofuel production. Environmental Research Letters. 15(8), 084014. DOI: 10.1088/1748-9326/ $\mathrm{ab} 794 \mathrm{e}$

Liu, Q., Xu, Z., \& Hao, Z. (2021). Low carbon economy and agricultural development. E3S Web of Conferences. 236, 03005. DOI: 10.1051/ e3sconf $/ 202123603005$

Louche, C., Busch, T., Crifo, P., \& Marcus, A. (2019). Financial markets and the transition to a lowcarbon economy: Challenging the dominant 
logics. Organization \& Environment. 32(1), 3-17. DOI: $10.1177 / 1086026619831516$

Lu, J., \& Sun, X. (2021). Carbon regulations, production capacity, and low-carbon technology level for new products with incomplete demand information. Journal of Cleaner Production. 282, 124551. DOI: 10.1016/j.jclepro.2020.124551

Lyashenko, A. N. (2015). Konceptualizaciâ upravleniâ èkonomičeskoj bezopasnost'û predpriâtiâ: monografiâ (Conceptualization of management of economic security of the enterprise: monograph), 348, NISD.

Michael, R. Bloomberg has been named the first global ambassador for the Race to Zero and Race to Sustainability movement, from http:// racetozero.unfccc.int/michael-r-bloombergnamed-first-global-ambassador-for-race-tozero-and-race-to-resilience/

Ministry of Energy and Environmental Protection of Ukraine. (2019). Ukraine's Greenhouse Gas Inventory 1990-2017, from http://mepr.gov.ua/ files/docs/Zmina_klimaty/kadastr2017/Ukraine_ NIR_2019_draft.pdf

Ministry of Energy and Environmental Protection of Ukraine. (2020). Ukraine's Greenhouse Gas Inventory 1990-2018, from http://mepr.gov.ua/ files/docs/Zmina_klimaty/2020/Ukraine_NIR_2 020\%20draft.pdf

Monnin, P. (2018). Central Banks and the Transition to a Low-Carbon Economy, from http:// www.cepweb.org/wp-content/uploads/2018/03/ CEP-DN-Central-Banks-and-the-Transition-toa-Low-Carbon-Economy.pdf

National Inventory Submissions. 2020, from http:// unfccc.int/ghg-inventories-annex-i-parties/2020

New UNEP Synthesis Provides Blueprint to Urgently Solve Planetary Emergencies and Secure Humanity's Future. 2021. UNEP press release, from http://unfccc.int/ru/news/novyy-obzoryunep-eto-srochnyy-plan-resheniyaplanetarnykh-chrezvychaynykh-situaciy-iobespecheniya

Nyambuu, U., \& Semmler, W. (2020). Climate change and the transition to a low carbon economyCarbon targets and the carbon budget. Economic Modelling. 84, 367-376. DOI: 10.1016/ j.econmod.2019.04.026

On ratification of the UN Framework Convention on climate change. (1996). Law of Ukraine from № 435/96-BP, from http://zakon.rada.gov.ua/ laws/show/435/96-\%D0\%B2\%D1\%80\#Text

Owen, R., Brennan, G., \& Lyon, F. (2018). Enabling investment for the transition to a low carbon economy: government policy to finance early stage green innovation. Current Opinion in
Environmental Sustainability. 31, 137-145. DOI: 10.1016/j.cosust.2018.03.004

Paris agreement. (United Nations, 2015), from http:// unfccc.int/sites/default/files/english_paris_agree ment.pdf

Resolution, U. G. A. (2000). 55/2, United Nations Millennium Declaration, UN Doc. A/RES/55/2, from http:/www.un.org/en/development/desa/ population/migration/generalassembly/docs/glo balcompact/A_RES_55_2.pdf

Richardson, K., Steffen, W., \& Liverman, D., (Eds.) (2011). Climate Change: Global Risks, Challenges and Decisions. (Cambridge University Press). DOI: 10.1017/cbo9780511973444

Prokopenko, O. M. (2020). The Statistical Yearbook "Agriculture of Ukraine" for 2019 contains information about social and economic state of agriculture in Ukraine and its regions for 20002019. State Statistics Service of Ukraine, from http://www.ukrstat.gov.ua/druk/publicat/kat_u/2 020/zb/09/zb_sg_Ukr_2019.pdf

Shuai, C., Chen, X., Wu, Y., Zhang, Y., \& Tan, Y. (2019). A three-step strategy for decoupling economic growth from carbon emission: Empirical evidences from 133 countries. Science of The Total Environment. 646, 524-543. DOI: 10.1016/ j.scitotenv.2018.07.045

Slobodianyk, A., \& Abuselidze, G. (2019). Prospective of Provision of Dairy Products for the Population of Ukraine. E3S Web of Conferences. 135, 01019. DOI: $10.1051 / \mathrm{e} 3$ sconf $/ 201913501019$

Support to the government of Ukraine on updating its nationally determined contribution (NDC) C40502/8492/47661. The Institute for Economics and Forecasting, NASU, 2020, from http:// mepr.gov.ua/files/images/news_2020/22122020/ Результати\%20моделювання.pdf

Taghizadeh-Toosi, A., \& Olesen, J. E. (2016). Modelling soil organic carbon in Danish agricultural soils suggests low potential for future carbon sequestration. Agricultural Systems. 145, 83-89. DOI: 10.1016/j.agsy.2016.03.004

Tapio, P. (2015). Towards a theory of decoupling: degrees of decoupling in the EU and the case of road traffic in Finland between 1970 and 2001. Transport Policy. 12(2), 137-151. DOI: 10.1016/ j.tranpol.2005.01.001

The European Commission proposed a Strategy on the Sustainable Use of Natural Resources used in Europe. (2005), from http://ec.europa.eu/ environment/eussd/

The Global Reporting Initiative 300. (2017). Environmental Disclosures. International Organization for Standardization, from http:// www.globalreporting.org/ 
The Roadmap to a Resource Efficient Europe. (2011), from http://www.eea.europa.eu/policy-documents/ com-2011-571-roadmap-to

Tkachenko, A., Levchenko, N., Pozhuieva, T., \& Chupryna, N. (2019). Innovative Approach to Evaluation of the Decoupling Phenomena in Making Decision on Investment of Agro-Business. International Journal of Recent Technology and Engineering (IJRTE). 8(3C), 38-44. DOI: 10.35940/ijrte.c1007.1183c19

United Nations framework convention on climate change. (United nations, 1992), from http:// nci.org.ua/npb.html\#zn doc

Wu, Y., Shuai, C., Wu, L., Shen, L., Yan, J., Jiao, L., \& Liao, S. (2020). A new experience mining approach for improving low carbon city development. Sustainable Development. 28(4), 922-934. DOI: $10.1002 / \mathrm{sd} .2046$

Zhan, C., \& de Jong, M. (2018). Financing eco cities and low carbon cities: The case of Shenzhen International Low Carbon City. Journal of Cleaner Production. 180, 116-125. DOI: 10.1016/ j.jclepro.2018.01.097

Zhang, H. (2020). Construction and Application of Low-Carbon Audit Evaluation Index System Based on Low-Carbon Economy. Modern Economy. 11(12), 2027-2040. DOI: 10.4236/ me.2020.1112135

Zhang, Y., Shen, L., Shuai, C., Tan, Y., Ren, Y., \& $\mathrm{Wu}, \mathrm{Y}$. (2019). Is the low-carbon economy efficient in terms of sustainable development? A global perspective. Sustainable Development. 27(1), 130-152. DOI: 10.1002/sd.1884

Zhang, Y., Gu, L., \& Guo, X. (2020). Carbon audit evaluation system and its application in the iron and steel enterprises in China. Journal of Cleaner Production. 248, 119204. DOI: 10.1016/ j.jclepro.2019.119204

Zhangping, X. I. N., \& Yintai, Z. H. A. N. G. (2008). Low Carbon Economy and Low Carbon City [J]. Urban Studies. 4, 98-102, from http:// en.cnki.com.cn/Article_en/CJFDTotalCSFY200804020.htm 